\title{
KURSI ESTETIS SEBAGAI UNSUR PENGUAT CITRA PADA INTERIOR RUMAH SAKIT
}

\author{
Siti Badriyah \\ Fakultas Seni Rupa dan Desain, \\ Institut Seni Indonesia (ISI) Surakarta \\ Email: badriyah@isi-ska.ac.id
}

\begin{abstract}
ABSTRAK
The design of the chair can be an alternative aesthetic enrichment for the visual appearance of a hospital. Many hospitals concerned in presenting the image and quality of service for the community even though the level kabupaten. Usaha complementary infrastructure, health care, medical needs and the interior architecture is also increasingly encouraged hospitals to meet the demands of society. Innovation in packaging designers help the image you want presented. Public awareness to use the services of interior designers began to increase in line with the demands of people's lifestyle is in line with industry asesories furniture and architecture, people are not enough to design the interior of the house or his hotel is not professional, but began to trust the experts. Departing from the above phenomena seat design aesthetic to the hospital is an answer to the demand for image performance wise a hospital. The design uses a systematic design method of imagination to reality through several processes namely : searching , planning , inventing and constructing. Chair design aesthetic even this is a process that starts from imagination to become reality design that is able to answer the demands of time for the service and comfort of a wellness center for the community.
\end{abstract}

Keywords : aesthetic seats, interior lobby hospital

\section{PENDAHULUAN}

Rumah sakit di kota Klaten merupakan pemenuhan kebutuhan yang sangat vital bagi pelayan kesehatan masyarakat, meskipun rumah sakit yang dikelola pihak swasta kehadirannya merupakan harapan yang lebih baik bagi persaingan pelayanan rumah sakit yang bisa memberi pilihan bagi masyarakat demikian juga rumah sakit negeri tidak mau ketinggalan. Mereka berlomba-lomba dalam menghadirkan mutu pelayanan bagi masyarakat meskipun setingkat kabupaten. Usaha melengkapi sarana dan prasarana, pelayanan kesehatan, kebutuhan tenaga medis juga arsitektur dan interior rumah sakit kian digalakkan untuk pemenuhan tuntutan masyarakat.

Penanganan interior tak kalah kompetitif dalam penampilan, baik pembentuk ruang maupun pengisi ruang menunjukan usaha pembenahan yang bersifat positif. Jasa desain interior banyak yang digunakan untuk mengemas keinginan pengelola, baik merancang interior secara menyeluruh maupun terpisah antara pelaksana pembentuk ruang berbeda dengan pelaksana pengisi ruang atau hanya furniturnya. Desainer menterjemahkan 
keinginan pemilik rumah sakit (owner) untuk mendesainkan interior dengan karakter tertentu sesuai tema yang ingin dihadirkan. Kesadaran masyarakat untuk menggunakan jasa desainer interior mulai meningkat sejalan dengan tuntutan gaya hidup masyarakat hal ini sejalan dengan industri mebel dan asesories arsitektur, masyarakat tidak cukup untuk mendesain interior rumah atau hotelnya secara tidak professional, melainkan mulai mempercayakan kepada ahlinya. ${ }^{1}$

Berangkat dari fenomena diatas lahirlah sebuah rancangan kursi pada rumah sakit swasta di kota Klaten. Rumah sakit inipun tidak bisa lepas dari kompetisi berbenah diri dari segi pelayanan maupun keindahan interiomya, dengan konsep yang merepresentasikan tekad rumah sakit untuk menangani hingga molekul hayat terkecil dari tubuh manusia sehingga ekspresi analog metabolisme molekul tercermin dalam bentuk visual ornament pada backchair kursi tersebut. Dengan pertimbangan backchair merupakan area visual strategis dalam struktur kursi. Kursi ini berfungsi sebagai elemen estetis "doorguard" pengapit pintu main entrance.

Perancangan atau desain dari imajinasi hingga realitas melewati beberapa proses yakni : searching, planning, inventing dan construcfing. Perancangan menjadi sebuah proses selektif terhadap kelemahan serta kekurangan dalam proses produksi. Beragam problematika dalam proses produksi menuntut reflek dan fleksibilitas untuk dapat menentukan prosedur kerja/ produksi yang lebih efisien serta efektif. Mata rantai kerja produksi khususnya furniture workshop, secara berurutan adalah desain, produksi,intermediasi, promosi \& marketing. Mata rantai produksi diworkshop merupakan tahapan yang sangat kritis, karena menyangkut modal kerja dalam bentuk upah, bahan baku

1 Agus Sachari \& Yan Yan Sunarya, 2002, Sejarah dan Perkembangan Desain \& dunia Kesenirupaan di Indonesia, ITB, Bandung, p. 136 serta operasi mesin. ${ }^{2}$ Perancangan kursi estetis inipun merupakan proses yang berawal dari imajinasi hingga menjadi realitas desain. Proses desainnya mendapat sedikit masukan dari pihak pengelola rumah sakit sehingga diharapkan bisa menghadirkan seperti karakter yang diinginkan.

\section{Pembahasan}

Rancangan kursi yang berfungsi sebagai kursi estetis yang mencerminkan slogan rumah sakit merupakan jawaban bagi kebutuhan khusus sebuah interior performance tertentu. Rancangan yang bertujuan untuk mewujudkan desain kursi yang berfungsi sebagai kursi estetis yang mencerminkankan slogan corporation pada rumah sakit, yang secara umum bertujuan sebagai wacana dan penambah wawasan visual bagi masyarakat sebagai nilai tambah bagi penampilan interior. Sasaran perancangan kursi estetis molecules live chair dirancang khusus sebagai kursi pengapit pintu entrance interior lobby rumah Sakit Mitra Klaten. Originalitas beberapa karya desain kursi estetis banyak yang menampilkan kreativitas dengan imaginasi yang masih mengarah pada konsep fungsi praktis, pengembangan kearah non fungsi di kalangan masyarakat desainer Indonesia masih terlihat belum total dalam berkarya. Dalam perancangan kursi estetis kali ini mengedepankan tema tetapi masih terikat fungsi praktis bahwa kursi masih memungkinkan untuk menyangga beban orang duduk. Ide dari kursi ini sangat asli yang muncul dari pemikiran merefleksikan tekad rumah sakit dalam mengobati hingga sel atau molekul terkecil dari tubuh manusia.

\section{Kerangka Pikir}

Perancangan kursi estetis ini menggunakan metode pemecahan masalah 2 Diktat Kuliah Praktek Bengkel Mebel FSRD ITB, Oleh: Deny Willy,2012,p. 1 
dengan pendekatan tidak saja perseptual tetapi yang lebih utama adalah konseptual, adalah dasar pemikiran desainer dalam memecahkan permasalahan yang berkaitan dengan pemilik, pendataan dan lingkungan. Secara umum konsep merupakan ide atau pengertian yang diabstraksikan dari peristiwa konkrit (Depdikbud, 1992), Melalui metode pendekatan untuk memenuhi tuntutan dari pihak-rumah sakit sebagai berikut:

\subsubsection{Pendekatan Estetis dan Ergonomi}

Perancangan sebuah kursi estetis selalu terintegrasi dengan aspek estetis desain danergonomi. Unsur estetika terkonstruksi dalam desain interior yang pada dasarnya adalah pembentuk estetika dan diolah ke dalam prinsip-prinsip estetika yang terdiri dari proporsi, keseimbangan, kesatuan, irama, komposisi, vocal point danlainnya. Produk karya seni dan budaya dalam masyarakat seperti halnya desain sangat bergantung kompleksitas beberapa aspek (seperti ideologi, kepercayaan dan lain-lain), kemunculannya dalam komunitas masyarakat sangat berkaitan erat dengan situasi dan kondisi masyarakat itu sendiri seperti yang diutarakan oleh Steiner sebagai berikut:

The Ideological character of works of art and cultural products is recognizedto be extremely complex, their determination by economic and other materialfactors mediated both by the existence and composition of social groups, and bythe nature and interrelationship of their ideologies and consciousness. ${ }^{3}$

Menurut Prof. Sartono, teknologi sendiri akar katanya adalah "techne" yang artinya adalah "art" atau seni. Seni menyentuh langsung pada kehidupan manusia. Jadi seharusnya seni adalah bagian yang tak terpisahkan dari teknologi, agar teknologi menjadi manusiawi (Widodo, 1999). 3 Steiner(1969, p. 271), Arvon(1973, pp. 36-7)
Sedangkan kreativitas inovasi desain sangat tergantung pada tinggi rendahnya pengetahuan dan daya logika atau pikiran yang berorientasi positif. Semakin tinggi kemampuan perancang dalam bernalar, semakin canggih dan semakin kritis dalam memecahkan masalah.

Sedangkan unsur teknis yang menjadi garapan dalam desain interior adalah civitas; elemen pembentuk ruang; elemen pelengkap pembentuk ruang; fasilitas ruang; utilitas ruang; dekorasi dan aksesoris ruang; main entrance; maintenance, peranan seni dalam pengertian cita rasa estetis juga memang relatif terhadap waktu dan tempat. Produk karya yang diciptakan sebagai jawaban sebuah tuntutan kehidupan saat ini, lambat laun akan menjadi usang bagi masa berikutnya. Karena perkembangan cita rasa seni akan selalu berubah sesuai perkembangan ekonomi, sosial, politik dan budaya masyarakat. Beberapa aspek pendekatan pemecahan desain menyesuaikan tuntutan kebutuhan selalu merupakan perangkat vital dalam desain. Ergonomi dipastikan harus membingkai ke tiga unsur besar dalam desain interior tersebut, sebab bagaimanapun desain interior yang diwujudkan akan digunakan oleh manusia,oleh karena itu, harus mampu memberikan kenyamanan dan keamanan. ${ }^{4}$ Estetika adalah suatu kondisi yang berkaitan dengan sensasi keindahan yang dirasakan seseorang, dan akan dirasakan apabila terjalin perpaduan yang harmonis darielemen-elemen keindahan yang terkandung pada suatu objek (Artini, 2000).

Pemahaman desain sebagai seni yang merupakan keindahan visual, maka akan berhubungan dengan unsur-unsur pembentuk seni: titik, garis, bidang, bentuk, tekstur, pola, cahaya, bahan dalam suatu keseimbangan, harmoni, irama, kesatuan, komposisi, nada 4 http:forum.isi-dps.ac.id. Konsep Estetika dan Tehnis dalam Bingkai Ergonomi total dalam Desain interior 
titik pusat perhatian serta proporsi dan lain sebagainya. Komponen yang terstruktur dalam kerangka pikir sebuah desain ruang membentuk desain interior istimewa begitupun desain mebel yang mampu mewujudkan nilai simbolik dan budaya bagi masyarakatnya . Prinsip dasar desain pada desain mebel adalah sebuah bentuk desainmemiliki prinsip dasar yang jelas, didasarkan pada konsep bentuk yang disesuaikan dengan fungsi dan aktivitas pemakai, kesesuaian bahan yang dipilih, sistem konstruksi yang benar serta pemakaian bahan finishing yang tepat. Demikian juga mengenai volume (besaran) dengan dimensi (ukuran) dan standard yang ergonomis dan anthropometris. Memperhatikan pengerjaan detil atau profil, pemilihan jenis assesoris dengan teliti, disesuaikan dengan gaya (style) desaintersebut, dalam upaya menghasilkan desain fungsional, ergonomis dan estetis.Selain itu, desain mebel sebagai salah satu kategori elemen desain yang pasti ada di hampir semua desain interior, sebagai bagian dari terhadap komponen. Desain Mebel Dalam Pendidikan Seni dan Desain. ${ }^{5}$ Desain merupakan hasil dari sebuah proses berfikir yang berlandaskan pada ilmu pengetahuan yang bersifat rasional dan pragmatis. Mendesain berarti melaksanakan suatu rentetan kegiatan yang menggabungkan daya cipta, penguasaan perkembangan teknologi, dan unsur estetika yang memenuhi syarat untuk diproduksi.

Desain adalah kegiatan pemecahan masalah dan inovasi teknologis yang bertujuan untuk mencari solusi terbaik dengan jalan memformulasikan terlebih dahulu gagasan inovatif ke dalam suatu model, dan kemudian merealisasikan kenyataan secara kreatif. Sekalipun desain itu adalah disiplin keihnuan yang menyangkut sains alam (hal-hal yang fisis) dan sains sosial yang menyangkut perilaku 5 http://puslit.petra.ac.id/journals/interior/Laksmi Kusuma Wardani (behavior), peranan seni dalam pengertian cita rasa estetis juga memegrelatif terhadap waktu dan tempat. Apa yang dipecahkan saat ini, cepat atau lambat menjadi usang. ${ }^{6}$ Desain baik juga diformulasikan oleh Herbert Lindinger (dalam Widagdo 2001:196-197), yang dapat dimasukkan dalamkategori Die Gute Form adalah yang memenuhi 10 perintah (The Comandments), yakni:

1. Tingkat kegunaan yang tinggi.

2. Aman

3. Produk berumur panjang dan tidak cepat usang

4. Ergonomis

5. Mempunyai watak mandiri dari segi teknis maupun bentuk

6. Mempunyai tingkat kesesuaian yang tinggi dalam lingkungannya

7. Ramah lingkungan

8. Cara kerja produk mudah dipahami

9. Kualitas bentuk yang tinggi

10. Mampu menstimulasi perasaan.

Ada beberapa hal yang perlu diperhatikan dalam mendesain furniture yaitu:

- Tujuan pemakaian

- Keinginan pemakai

- Fungsi furniture

- Bentuk/ kesan/ penampilan luar

- Bahan yang dipakai

- Konstruksi atau cara pembuatan (M. Gani Kristianto. 1993. Hal 1).

Beberapa hal penting tersebut mengkonstruksi kualitas desain, dalam perancangan tidak akan lepas dengan citra 6 Laksmi Kusuma Wardani.2012, 136 
dan pesan yangakan disampaikan meskipun melalui pesan simbolik yang kaya makna. Dimana tampilan visualnya menyiratkan nilai budaya yang merupakan substansi pesan yang akan dilahirkan dalam sebuah desain. Seperti yang diungkapkan oleh Santosa (2005) sebagai perwujudan nilai simbolik dan budaya, maka desain dapat dikaitkan dengan faktor nilai, pandangan hidup, kepercayaan, mitos dan lainlain ke dalam wujud materi yaitu benda kongkrit yang berfungsi untuk rnengungkapkan suatu nilai budaya tertentu.

\section{Ide Perencangan}

Kontruksi dan Bahan: konstruksi kursi dari bahan baku kayu (jati) yang memiliki kualitas kekuatan baik, yaitu jenis kayu yang kuat menahan beban dan berjalannya waktuhal halyang berkait dengan karakteristik bahan baku sangat perlu diperhatikan dalamsebuah perancangan, baik visualisasi bahan (serat, wama dan mata kayu), kadar kelembaban kayunya. Tiap jenis kayu apapun memiliki kelembaban relatif yang tetap diperlukan oleh kayu tersebut. Ambang batas normal kelembaban kayu biasa berbeda-beda bila mengacu peraturan Departemen Kehutanan, di negara eropa terdapat standar dengan klasifikasi berdasarkan penggunaan kayu pada bangunan, contohnya untuk kategori interior ruang tamu, mang tidur, kantor dan juga eksterior. Namun umumnya untuk bahan interior berkisar $10 \mathrm{~s} / \mathrm{d} 14$ per cent $\left(+/-6 s / d 9\right.$ liter per $\left.\mathrm{M}^{3}\right)$. Pengukuran terhadap kadar kelembaban kayu menggunakan alat hygrometer. ${ }^{7}$ Sedangkan bahan baku dari desain ini juga mengalami proses pengeringan secara alami (air drying) tanpa kiln drying. Sehingga bahan baku siap untuk diwujudkan dalam desain yang dikehendaki.

7 Diktat Kuliah Praktek Bengkel Mebel FSRD ITB, Oleh: Deny Willy,2012,p. 19
Pertimbangan yang vital bahwa bahan yang akan kita gunakan yaitu kayuyang secara teknis baik dalam konstruksi sambungan. Teknik sambungan kayu telah berevolusi sejak berabad-abad yang lalu berkembang sesuai kebutuhan, dan kreasi baru. Bahkan variasinya juga berkembang menjadi trend estetika. Pada dasarnya semua teknik sambungan kayu dimaksudkan untuk menjaga stabilitas serta mengencangkan hubungan satu bagian kayu dengan bagian yang lainnya (Self-supporting) hingga tercapai keteguhan dan rigiditas. Pertimbangan terhadap beragam teknik sambungan kayu bermuara pada 2 hal utama yakni :

1. Perubahan fisik yang disebabkan oleh sifat-sifat alamiah kayu, seperti pergeseran, pergerakkan, penciutan, pemuaian.

2. Menahan, Mengunci antar bagian kayu baik dalam posisi sejajar atau berlawanan atau bersimpangan agar mampu menahan tekanan, gaya tarik, dorong,tekan (suspension and tension moment), tumbukkan, gesekan, beban kejut (sudden-impact).

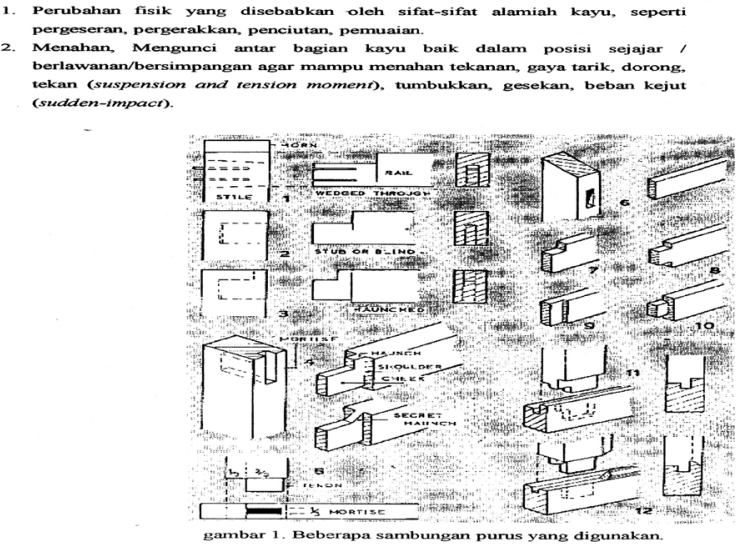

Gambar 1. Beberapa sambungan purus yang digunakan.

Dalam Paku, Sekrup dan Dowel merupa- 
kan satu mekanisme pengencangan sambungan kayu yang sangat baik, selain kuat pemasangannyapun relatif mudah. Pada perkembangannya dua jenis pengencang Sekrup dan Dowel semakin dimodifikasi menjadi jauh lebih baik dari segi, kekuatan, mekanisme, mutu baha$\mathrm{n}$ (tahankarat), dan estetikanya. Paku umumnya berkembang pada konstruksi arsitektur dan interior, namun pada pekerjaan kayu, paku digunakan untuk beberapa hal seperti pembuatan mock-up, juga untuk mengencangkan upholster dengan kayu. Paku merupakan pengencang yang sangat tradisional, paku yang dikendalikan atas tumpuan ketuk sangat sulit dijamin kelurusannya sehingga menjadi hal yang kurang menguntungkan dalam proses produksi furnitur.

Beberapa jenis paku yang sering ditemui dalam furnitur sebagai perencana interior selain dituntut kecermatan teknis juga kemampuannya dalam membaca estetika yang tepat terutama dalam hal pemilihan bahan. Begitupula kecermatan kita dalam dalam mengenal beberapa karakteristik kayu sebagai berikut:

- Urat kayu (grain), ia dapat meningkatkan kualitas atau menentukan citra dan kelas pengguna (form follows mean).

- Tekstur, ragam jenis tekstur juga sangat berpengaruh terhadap kerapihan, keindahan proses finishing

- Figur, variasi atas wama-wama alami kayu, kekhasan, keunikan atau motifalamiah tertentu. Ketidakseragaman garis tahun yang memiliki keunikanmasing-masing

- Scrap Warna, faktor serap wama yang sangat berbeda dari tiap jenis kayu sehingga dapat merubah penampilan.
- Wewangian (odour), wangi yang dihasilkan dan dampaknya juga menjadi pertimbangan desain.

- Durabilitas, mutu kuat kayu yang dilihat dari kelas awet, jenis dan harga perlu dipertimbangkan oleh para perencana.

- Daya tahan terhadap api, pertimhangan jenis kayu dan komposisi kimiawinya yang resisten terhadap api.

\section{Cacat pada kayu (defects)}

Cacat pada kayu dapat dibagi menjadi dua, yakni cacat alam yang terjadi karena proses alamiah dan fitrah kayu tersebut. Yang lainnya adalah cacat buatan yang terjadi karena kelalaian atau ketidaksempumaan dalam pemrosesannya. Penyakit pada Kayu merupakan makanan utama serangga, pencegahannya dapat dilakukan pada saat kayu masih sebagai bahan mentah/siap pakai (raw-material) maupun setelah menjadi produk. Proses perlindungannya dapat menggunakan penyemprotan cairan kimia anti serangga atau melapisinya. Dampak serangan serangga menimbulkan efek yang bermacam-macam, seperti jamur, debu dan lubang-lubang yang ditinggalkannya, namun yang paling dikhawatirkan adalah keropos pada kayu. Keuntungan kayu solid:

- Sambungan lebih mudah dibentuk

- Mudah diukir

- Tidak perlu cover untuk menutupi bagian tepi (edging)

- Sekrup dan paku lebih kencang

- Permukaan yang baik untuk finishing (natural). ${ }^{8}$

8 Diktat Kuliah Praktek Bengkel Mebel FSRD ITB, Oleh: Deny Willy,2012,p.20-21 
Serat kayu diperlihatkan untuk mengekspresikan kesan analog urat tubuh manusia atau jalinan yang saling menghubungkan molekul hayat dalam metabolisme tubuh manusia jalinan urat-urat yang dihadirkan serat kayu tampak memberikan nilai estetis secara alami. Sebagai konstruksi utama kayu jati Nampak kokoh diaplikasi dengan sambungan purus dan pen secara tradisional diperkirakan mencukupi bagi sebuah kursi estetis yang jarang menanggung beban berat. Sedangkan aplikasi ornament terbuat dari steel plate $3 / 30 \mathrm{~mm}$ untuk mempermudah pembuatan bentuk akar-akar urat sekaligus sebagai penguat konstruksi kayu bagi backchair, batangan besi yang berujud akarakar tersebut menghubungkan kesan molekul yang terdiri dari busa cover vinyl (ex.auto leader)yang hadir dalam tampilan bentuk bulat-bulat yang mengekspresikan molekul-molekul hayat dalam tubuh manusia.

\section{Finishing}

Proses finishing rancangan kursi ini membutuhkan tahapan-tahapan procedural yang terkondisi iklim, cuaca dan waktu. Bahkan dalam finishing juga ada bagian yang bersifat restorasi terhadap bahan baku yaitu kayu jati sebagai konstruksi utama. Restorasi fumitur merupakan proses perawatan atau pelestarian terhadap mebel atau furnitur untuk menghilangkan dan mengganti bagian-bagian yang telah cacat dengan mempertimbangkan aspek orisinalitasnya serta perawatan, seperti membuang sisa-sisa bekas perekat, dls. Perawatan terhadap furniture yang rusak karena usia maupun penggunaan, menuntut pengetahuan khusus untuk mendapatkan hasil yang baik. Pengetahuan khusus tersebut berupa pemahaman tentang periodisasi, teknik ukir, bahan dan teknik finishing tradisional, serta penguasaan sifat kimiawi dan fisik kayu. Keputusan-keputusan ekstrim juga perlu diambil seperti membongkar konstruksi, atau bahkan memotong bagian yang telah dimakan rayap (worm-eaten) atau ulat kayu dan mengganti dengan kayu baru yang sesuai. ${ }^{9}$ Finishing yang digunakan adalah politur clear brown yang memberikan dampak visual urat kayu nampak seperti yang diharapkan. Sedang untuk ornament diselesaikan dengan finishing cat besi wama biru tua (ex. Dextro). Pemilihan warna berdasarkan pada pengintegrasian dengan warna bini muda dinding mayoritas rumah sakit. Dalam hal ini, mebel menjadi perantara antara manusia dan ruangnya.

Menawarkan adanya transisi bentuk dan skala antara ruang interior dan manusia. Membuat interior dapat dihuni karena memberikan kenyamanan dan manfaat dalam pelaksanaan aktivitasnya. Dengan demikian, dapat disimpulkan bahwa desain mebel tidak bisa lepas dari pertimbangan desain interior (kesesuaian, keselarasan, keseimbangan dan unity antara mebel dengan ruangnya). Sehingga kursi diharapkan mampu mengintegrasi dengan interior melalui warna.

\section{Proses Desain}

Dalam perancangan kursi estetis ini melalui serangkaian tahapan yang tersism dalam sebuah metode desain. Proses desain melibatkan berbagai permasalahan yang sifatnya tidak statis dan membutuhkan pemikiran kritis dan kreatif dalam menggabungkan daya cipta, perkembangan teknologi, dan unsur estetika yang memenuhi syarat untuk diproduksi. Terjadi perbedaaan pemecahan masalah yang berlaku di satu kasus dalam desain mebel, berbeda pada kasus yang lain. Keberhasilan desain sangat ter-

9 Diktat Kuliah Praktek Bengkel Mebel FSRD ITB, Oleh: Deny Willy,2012,p.80 
gantung pada proses desain yang teraplikasi secara cermat dan dalam framework yang terkontrol. Perancangan desain mebel juga melewati suatu proses desain yang sistematis (walaupun kadang-kadang ada loncatan gagasan), antara lain tahap analisis, konsep desain, penggalian ide atau pemecahan masalah, pengembangan desain, dan penyajian gambar presentasi (gambar tampak dan gambar detil). Tahapan tersebut digunakan untuk menata, membangun dan menstrukturkan kesadaran pikir yakni melihat subject matter secara lengkap, menyeluruh, dan mendekati kenyataan, sehingga dapat dianalisisdan dijelaskan secara komprehensif, holistik dan tuntas. Hampir sebagian besar metode merupakan upaya untuk membeberkan kepada publik bahwa pemikiran para desainer bersifat privat, atau dengan perkataan lain adalah upaya untuk mengekstemalisasikan proses desain. Dalam kasus tertentu dapat dilakukan dalam kata-kata simbol matematis dan hampir selalu dengan diagram untuk menggambarkan bagian dan hubungannya. Mayoritas metode desain berkenaan dengan pemikiran yang dieksternalisasikan dan karena itu didasarkan pada asumsi-asumsi rasional daripada yang mistis. (ChristopherJones.1980,49).

\section{Tahapan Proses Desain}

Tahapan proses desain digambarkan secara garis besar dari Input-Proses-Output. Pada bagian tahapan input ini terdapat latar belakang masalah (data lapangan), masalah dari kasus yang diangkat atau berbagai tuntutan owner dan kondisi atau situasi yang mesti dipertimbangkan terangkum atau diidentifikasi secara cermat baik itu mengenai data penikmat (ekonomi, social dan budaya), data situasi interior yang akan diisi kursi tersebut (baik wama, pola, texture, dan tata kondisi ruang ), data harga bahan baku di pasaran, dan data-data pendukung lain yang diperlukan untuk mempermudah proses mendesain dan produksinya.
Tahapan proses mencakup tahapan berikutnya yang mensintesa (mengelompokan mana yang perlu dan mana yang urgen, mana yang harus atau mana yang sekedar pendukung atau disebut proses memilah dan memilih ataumereduksi data ). Semua tahapan input atau data-data yang telah terinventaris kedalam tuntutan desain dari owner (sebagai sebuah konsep desain) akan dipadukan dengan literatur, parameter (pembanding), kriteria-kriteria, misalnya kriteria khusus yaitu ramah lingkungan, penyesuaian terhadap iklim dan site, bahan alami, bahan finishing yang aman juga tema yang harus divisualkan dan terintegrasi dengan interiornya. Kriteria umum yaitu aman, nyaman, lancar, fungsional, komunikatif, efisien, ergonomis, estetis. Substansi dari tahapan prosesini adalah data yang dipadukan adalah data lapangan (data sosial, ekonomi, budaya penikmat) dan data interior, dipadukan dengan literatur dan parameter, yang disesuaikan dengan konsep yang kemudian dianalisis diuraikan sesuaituntutan yang harus diwujudkan dengan arahan framework literature yang baku bagi desain kursi.

Tahapan Output adalah langkah berikutnya yang secara urut dalam tahapan berikutnya. Setelah proses analisis dari data dan literature juga parameter yang disingkronkan dengan konsep desain didapatkanlah gagasan dan ide yang digunakan untuk pradesain sebelum desain akhir ditemukan. Dalam hal ini penulismendapatkan ide atau gagasan dari tema yang nadir adalah imajinasi dari struktur molekul hayat yang terefleksi sebagai ornament backchair.

\section{Analisis Altematif Desain Terpilih}

Dari data yang telah direduksi dan dianalisis berdasarkan tuntuan desain dari owner (rumah sakit) sesuai tahapan yang sistematis akan 
lebih mudah mengontrol hal-hal yang menyimpang dari parameter atau literature yang telah ditetapkan. Dengan beberapa alternatif desain pilihan dan menetapkan kriteria pemilihan alternatif sesuai dengan beberapa kriteria misalnya sebagai berikut: tingkat kegunaan yang tinggi, aman, produk berumur panjang dan tidak cepat usang, ergonomis, memiliki watak mandiri dari segi teknis maupun bentuk, mempunyaitingkat kesesuaian yang tinggi dalam lingkungannya, ramah lingkungan, cara kerja produk mudah dipahami, kualitas bentuk yang tinggi, mampu menstimulasi perasaan. Dalam hal melahirkan gagasan yang melahirkan alternative desain yang memiliki kriteria yang seperti diatas terkadang antara alternative satu dengan yang lain belum tentu bisa tercover dalam beberapa alternative desain, sehingga dicari skala prioritas yang mendekati tuntutan desain yang diinginkan owner. Tahapan ini bagi penulis diimplementasikan dalam gambar sketsa model secara freehand yang dilengkapi wama sehingga lebih mudah dalam menuangkan imajinasi sesuai tuntutan desain. Melahirkan beberapa sketsa model dengan pengembangan pada bentuk dasar desain kursi, pengembangan pada modifikasi material dan finishing, pengembangan pada detail dan konstruksi. Sehingga bisa dihasilkan berlembar-lembar sketsa yang mempermudah dalam tahap eksplorasi ide. Berikut adalah beberapa sketsa model yang dilengkapi keterangan material, finishing serta dilengkapi dengan kriteria pemilihan alternatif sketsa model yang akan dipinh sebagai desain pinhan danakan dibuat gambar desain.

\begin{tabular}{|c|c|c|c|c|}
\hline \multirow{2}{*}{ Sketsa model } & \multicolumn{2}{|c|}{ Kriteria desain } \\
\cline { 3 - 4 } & $\begin{array}{c}\text { Tem- } \\
\text { atik }\end{array}$ & $\begin{array}{c}\text { Este- } \\
\text { tis \& } \\
\text { ergon- } \\
\text { omis }\end{array}$ & Nilai \\
\hline
\end{tabular}

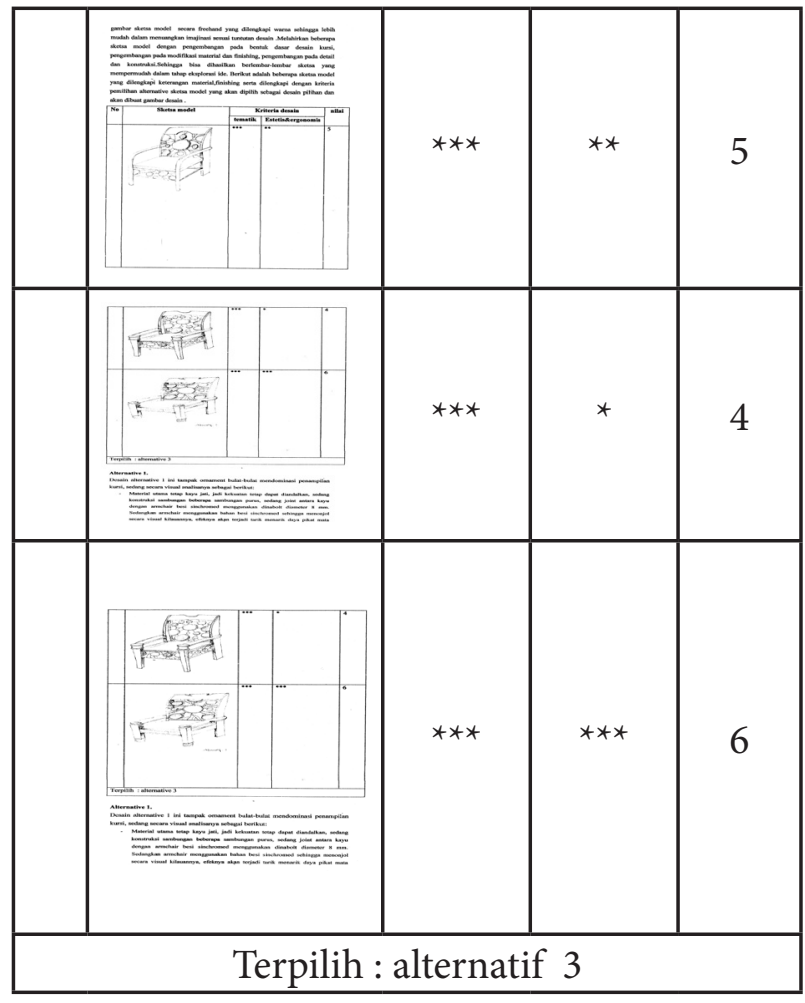

Alternatif 1.

Desain alternatif 1 ini tampak ornament bulat-bulat mendominasi penampilan kursi, sedang secara visual analisanya sebagai berikut:

- Material utama tetap kayu jati, jadi kekuatan tetap dapat diandalkan, sedangkonstruksi sambungan beberapa sambungan purus, sedang joint antara kayu dengan armchair besi sinchromed menggunakan dinabolt diameter $8 \mathrm{~mm}$. Sedangkan armchair menggunakan bahan besi sinchromed sehingga menonjol secara visual kilauamiya, efeknya akan terjadi tarik menarik daya pikat mata kilauannya, efeknya akan terjadi tarik menarik daya pikat mata antara bentuk ornament dengan kilauan besi sinchromed sehingga terlihat ramai secara visual.

- Ukuran atau demensi kursi sama antara alternative satu dengan yang lain,seh- 
inggabukan merupakan kriteria pemilihan (tinggi duduk $45 \mathrm{~cm}$, kedalaman duduk $55 \mathrm{~cm}$,tinggi backchair $90 \mathrm{~cm}$ )

- Coverseat dan ornamentcover menggunakan kain bludru wama biru orange. Bahan cover ini jika diaplikasi di sebuah ruang publik akan rentan debu meskipun area iniber-AC Jetap saja banyaknya pengunjung memungkinkan kondisi menjadi kotor.

\section{Alternatif 2.}

Alternatif 2 ini memiliki bentuk desain dasar sama dengan alternatif 1 , perbedaaannya hanya pada armchair tetap digunakan bahan kayu, sehingga secara visual lebih unity penampilannya, sedangkan analisis beberapa aspek alternative desain 2 ini antara lain sebagai berikut:

- Material utama tetap kayu jati, jadi kekuatan tetap dapat diandalkan, sedang konstruksi sambungan beberapa sambungan punis, sedang joint antara kayu dengan armchair besi sinchromed menggunakan dinabolt diameter 8 nun. Sedangkan armchair menggunakan bahan yang sama yaitu kayu jati, efeknya terhadap desain terlihat menyatu dan semakin kuat.

- Ukuran atau demensi kursi sama antara alternative satu dengan yang lain,sehinggabukan merupakan kriteria pemilihan (tinggi duduk $45 \mathrm{~cm}$, kedalaman duduk $55 \mathrm{~cm}$, tinggi backchair 90 $\mathrm{cm}$ ) tidak ada perbedaan yang mendasar dengan alternatif lain, hanya ada penambahan penguat atau ornament bagian bawah seat.

- Coverseat dan ornament cover meng- gunakan vinyl warna biru orange. Bahan cover ini jika diaplikasi secara maintenance di area publik lebih mudah dan awet .

\section{Alternatif 3.}

Desain Alternatif 3 ini secara visual lebih mengutamakan penampilan temadan estetis, terlihat pada pola ornament yang meretleksikan molekul-molekul hayat terkecil manusia yang diwujudkan dengan pola rangkaian sambungan yang lebih alami dibanding alternatif lain, sehingga lebih artistic dan aspek estetis lebih ditonjolkan, juga ada detail pada rangka armchair dan backchairnya.

Ketiga alternatif diatas setelah ditempatkan pada ranah fungsi kursi, yaitu sebagai elemen estetis maka dipilih alternatif 3 yang memiliki nilai yang lebihbanyak dengan kriteria pemilihan yang telah ditetapkan.

Feed Back Control adalah tahapan Proses ini dilakukan untuk melakukan peninjauan kembali hasil yang telah ditemukan atau didapat supaya hasilnya akan lebih sempurna lagi dan sesuai dengan keinginan owner atau perancang. Apakah sudah ada ketidaksesuaian dengan parameter yang telah mendasari konsep desain, baik dan pemililian material, finishing, wama, pola atau motif dalam detail, sistem konstruksi yang diaplikasi, dan tidak menyulitkan dalam proses produksinya.

\section{A. Transformasi Ide ke dalam Gambar Kerja}

Tahapan berikutnya adalah tahapan Desain setelah pradesain, ada beberapa gambar yang disajikan untuk mempermu- 
dah proses produksi, yaitu gambar proyeksi yang antara lain adalah: (a) gambar tampak atas; (b) gambar tampak depan; (c) gambar tampak potongan; (d) gambar detail konstruksi; (e) gambar perspektif; (f) skema bahan dan wama.

\section{HASIL DAN PEMBAHASAN}

Karya kursi estetis molecules of life ini bagi rumah sakit adalah sebuah kebutuhan estetis bagi interior. Rumah sakit yang sudah mempunyai kesadaran desain dan selalu menuntut kualitas, maka desain kursi dengan mutu desain yang baik adalah konsekuensi yang logis. Hal mengenai desain, terutama desain mebel estetis , di dalamnya mencakup bukan hanya bentuk, bahan dan warna saja, tetapi yang lebih penting adalah fungsi, yaitu fungsi estetis yang mana apakah bisa menjawab kebutuhan sosial penikmat yang ada di rumah sakit. Selain itu, harus memperhatikan teknis dalam reproduksi, durabilitas, konstruksi, efisiensi material, ergonomi, teknis, estetis bentuk menjadi lebih menonjol, dan integrasi dengan interior rumah sakit tentunya aplikasi bahan dan finishing yang ramah lingkungan sangat penting. Desain dapat disesuaikan dengan tujuan, penampilan dan kenikmatan (kenikmatan untuk bergerak, memperbaiki, penyimpanan, dan membersihkan, serta kenikmatan pada ukuran, bentuk, proporsi dan daya lentur).

Predikat baik menurut Buchori (1986 : 84-87) tergantung pada sasaran danfilosofi desain, bahwa sasaran berbeda menurut kebutuhan dan kepentingan, serta upaya desain berorientasi untuk mencapai hasil optimal dengan biaya yang rendah, dengan memperhatikan faktor performansi (kenyamanan, kepraktisan,keselamatan, kemudahan dalam penggunaan, kemudahan dalam pemeliharaan, kemudahan dalam perbaikan), faktor fungsi (kelayakan, keandalannya, struktur, pengguna atau sistem tenaga, spesifikasi dari material: tipe, kekuatan danukuran), faktor produksi (desain harus memungkinan untuk diproduksi sesuai dengan metoda produk, sasaran pasar, penentuan harga, dan saluran distribusi), kepentingan produsen (identitas produsen dan status) dan kualitas bentuk (spirit dan gaya zaman, daya tarik, citra atau image, estetis, penyelesaian detail dan finishing, kombinasi bahan, kemungkinan bentuk-bentuk yang sesuai dengan struktur dan karakteristik bahan).

Karya desain kursi estetis ini memiliki beberapa kekurangan yang terjadi karena faktor ketidakcermatan dalam kontrol produksi sehingga mengakibatkan kursi memiliki sudut antara dudukan dengan sandaran punggungbackchair) tidak sesuai gambar kerja, hal ini didukung manpower yang kurang kapabel. Sehingga performance kursi kurang ergonomis, tetapi agak bisa dimaklumi dikarenakan kursi ini didesain dengan fungsi sebagai kursi estetis. Kelebihan kursi ini tematik yang merupakan wujud tekad rumah sakit dalam melayani secara optimal bagi masyarakat sangat terefleksi pada ornament pada backchair. Sehingga diharapkan bisa menstimulasi perasaan bagi penikmat secara visual.

Kursi menjadi perantara antara manusia dan ruangnya. Menawarkan adanya transisi bentuk dan skala antara ruang interior dan manusia Membuat interior dapat dihuni karena memberikan kenyamanan dan manfaat dalam pelaksanaan aktivitasnya utamanya sebagai point of interest salah satu sisi interior. Sehingga dapat disimpulkan bahwa desain mebel kursi ini selalu terintegrasi dengan pertimbangan desain interior (kesesuaian, keselarasan, keseimbangan dan unity antara mebel dengan ruangnya). Faktor-faktor pertimbangan tersebut dalam aplikasinya kadang sangat relatif sifatnya, hanya penikmat yang punya kapasitas dan taste of art 
yang secara konstruktif bisa menerjemahkan apa makna yang terkadung dari penampilan visualnya.

\section{KESIMPULAN}

Desain kursi estetis ini bagi rumah sakit adalah wujud kepedulian bagi pihak swasta untuk mengikuti kompetensi berbenah pada penampilan interior yang secara tidak langsung memberikan kepuasan visual bagi masyarakat, meskipun beberapa kekurangan tidak biasa luput dari produksinya tetap ada harapan bagipihak rumah sakit untuk memperkenalkan jati diri sebagai pelayan kesehatan optimal bagi masyarakat.

Kedepan penulis (dalam hal ini desainer) berharap bisa berkarya lebih baik dalam memanfaatkan potensi alam dengan kreativitas dan tawaran pasar yang menuntut terpenuhinya kebutuhan akan desain mebel estetis yang optimal Sedang bagi masyarakat semoga karya-karya estetis bisa membangun keberaoian untuk tampil lebih berkarakter, berjiwa, dan bermoral dalam mengkomsumsi mebel-mebel estetis, yang secara tidak langsung mampu menerjemahkan jati diri, citra bangsa dan budaya yang arif.

\section{DAFTAR PUSTAKA}

Buchori, Imam. editor Agus Sachari. 1986. Paradigma Desain Indonesia : Peranan Desain dalam Peningkatan Mutu Produk. Jakarta; CV. Rajawali.

Buchori, Imam. 2000. Refleksi Sent Rupa Indonesia: Perlunya Seni PadaPendidikan Tinggi. Jakarta: Balai Pustaka.

Diktat Kuliah Praktek Bengkel Mebel FSRD ITB, Oleh: Deny Willy,2012,p. 19

File, Modern Furniture, John Wiley, 1978

J. Pamuji Suptandar, 1999. Desain Interior: pengantar Merencana Interior untukMahasiswa Desain Interior dan arsitektur. Jakarta: Djambatan.

Kristanto. M Gani, Teknik Mendesain Perabot Yang Benar, Kanisius, Yogyakarta,1995.

Widagdo. 2000. Refleksi Sent Rupa Indonesia: Pendidikan dan Profesi Indonesia.Jakarta: Balai Pustaka.

Wolff, Janet, The Social Production of Art, 2"d,New York: New York UniversityPress, 1993 